\title{
USULAN PERBAIKAN KAPASITAS PRODUKSI DENGAN PENDEKATAN THEORY OF CONSTRAINT PADA DIVISI TEKSTIL PT. MULIA KNITTING FACTORY
}

\author{
Iphov Kumala Sriwana ${ }^{1)}$, Iveline Anne Marie ${ }^{2)}$ dan Yulius ${ }^{3)}$ \\ ${ }^{1)}$ Program Studi Teknik Industri, Universitas Esa Unggul, Jakarta \\ ${ }^{2)}$ Program Studi Teknik Industri, Universitas Trisakti, Jakarta \\ 3) Program Studi Teknik Industri, Universitas Tarumanagara, Jakarta \\ e-mail: yuliusxyrianz@ymail.com
}

\begin{abstract}
ABSTRAK
PT. Mulia Knitting Factory merupakan perusahaan yang bergerak di bidang tekstil dan garmen yang memproduksi benang, kain, pakaian dalam, T-shirt, dan polo shirt. Kapasitas produksi di perusahaan tidak dapat memenuhi demand yang diperlukan sehingga menimbulkan adanya bottleneck. Hal ini terjadi pada lini kerja Rib 11/16, 12/16, 13/16, 36/28, jahit, celup, cuci, peras, dryer, dan compactor merupakan constraint yang dapat menghambat aliran material dan berpengaruh terhadap keluaran dari sistem proses produksi. Tujuan penelitian adalah mengetahui stasiun kerja mana yang menyebabkan adanya bottleneck pada Departemen Knitting dan Departemen BDF, mengidentifikasi lini pembuatan kain dan lini pembuatan warna yang menjadi stasiun bottleneck dan menjadi sumber daya yang membatasi kapasitas berdasarkan pendekatan theory of constraint, memberikan usulan perbaikan yang tepat untuk PT. Mulia Knitting Factory. Adapun hasil yang diperoleh pada penelitian ini adalah biaya yang dikeluarkan untuk memenuhi kapasitas produksi sebesar Rp 36.962.592. Bottleneck CCR dan Non CCR pada Departemen Knitting terletak pada Rib inchi 11/16, 12/16, 13/16, Sk inchi 36/28 sedangkan bottleneck pada Departemen BDF terletak pada stasiun kerja jahit, celup, cuci, peras, dryer, dan compactor kemudian bottleneck dibuat ke dalam konsep DBR untuk mengetahui drum buffer rope. Biaya yang dikeluarkan perusahaan untuk meningkatkan kapasitas produksi per bulan sebesar Rp. 1.155.081.
\end{abstract}

Kata kunci: Bottleneck, Kapasitas Produksi, Drum Buffer Rope, Theory of Constraint

\begin{abstract}
PT. Mulia Knitting Factory is an enterprise engaged in the textile and garment producing yarn, fabric, underwear, T-shirts and polo shirts. The company production capacity can not meet the required demand, causing the bottleneck. This occurs in the working line Rib 11/16, 12/16, 13/16, 36/28, sewing, dyeing, washing, wring, dryer and compactor are constraints that may impede the flow of material and the effect on the output of the system production process. The research objective was to determine which work stations causes the bottleneck at the Knitting Department and the Department of $B D F$, identify line lines manufacture manufacturing of fabrics and colors into the station and become a resource bottleneck that limits the capacity based approach to theory of constraints, propose appropriate improvements to PT, Mulia Knitting Factory. The results obtained in this study is the costs incurred to meet the production capacity of $R p$ 36.962.592. Bottleneck CCR and non-CCR in Knitting Department is located at Rib-inch 11/16, 12/16, 13/16, 36/28 inches Sk while the Department $B D F$ bottleneck lies in the sewing, dyeing, washing, wring, dryer, and compactor bottleneck then made into the concept of DBR to know drum buffer rope. Costs incurred by the company to increase production capacity per month is Rp. 1.155.081.
\end{abstract}

Keywords: Bottleneck, Production Capacity, Drum Buffer Rope, Theory of Constraint 


\section{PENDAHULUAN}

Produk adalah hasil dari kegiatan produksi yang berwujud barang. Produk mempengaruhi kepuasan konsumen karena produk ditawarkan untuk memenuhi kebutuhan dan keinginan konsumen. Produksi adalah suatu kegiatan untuk memberi nilai tambah sehingga bermanfaat dalam memenuhi kebutuhan barang atau jasa yang dihasilkan.

Kapasitas produksi pada Departemen Knitting tidak dapat tercapai pada target produksi karena mesin produksi pada bagian knitting mempunyai banyak masalah seperti error ketika mesin sedang beroperasi, mesin sudah tua sehingga kapasitas produksi yang dihasilkan tidak maksimum. Dalam penelitian ini diperlukan theory of constraint untuk menyeimbangkan aliran produksi untuk tidak terjadinya bottleneck pada stasiun kerja.

PT. Mulia Knitting Factory merupakan perusahaan yang bergerak dalam divisi tekstil dan garmen. Dalam divisi tekstil, proses produksi dimulai dari proses knitting, timbang berat kain, quality control, jahit, celup, peras, dryer, dan compactor, dan packing. Setelah proses tersebut dilakukan, maka dilanjutkan dengan proses cutting, sewing, dan packing pada divisi garmen.

Tujuan penelitian adalah mengetahui stasiun kerja mana yang terjadinya bottleneck pada Departemen Knitting dan Departemen BDF, mengidentifikasi lini pembuatan kain dan lini pembuatan warna yang menjadi stasiun bottleneck dan menjadi sumber daya yang membatasi kapasitas berdasarkan pendekatan theory of constraint dan memberikan usulan perbaikan yang tepat untuk PT. Mulia Knitting Factory. Adapun hasil yang diperoleh pada penelitian ini adalah biaya yang dikeluarkan untuk memenuhi kapasitas produksi sebesar Rp 36.962.592. Batasan penelitian adalah penelitian yang diamati pada Divisi Tekstil yaitu kain Rib, Sk, dan Spandek, pengambilan data dilakukan selama 1 bulan dan penelitian dilakukan dengan pengamatan langsung. Manfaat penelitian adalah mendapatkan usulan perbaikan kapasitas produksi dengan mempertimbangkan adanya bottleneck pada stasiun kerja.

\section{Definisi Theory of Constraint}

Theory of Consraint adalah suatu filosofi manajemen yang pertama kali dikembangkan oleh Eliyahu M. Goldratt [1].

\section{Drum Buffer Rope}

Metode penjadwalan yang memusatkan pada stasiun kerja dan menggunakan prinsip-prinsip dasar TOC adalah sistem penjadwalan drum buffer rope (DBR). Sistem penjadwalan DBR digunakan dalam synchronous manufaturing yang diperkenalkan oleh Umble dan Srikanth [2]. Drum buffer rope merupakan metode yang digunakan TOC dalam mengatur aliran produksi, langkah awal dalam mengatur aliran produksi adalah membuat rencana produksi. Drum adalah laju produksi keseluruhan dari lini produksi. Setiap sumber produksi mengalami fluktuasi statistik dan gangguan pada saat mengolah bahan baku atau komponen. sebelumnya, maka buffer ditempatkan di depan sumber pembatas (constraint buffer). Buffer ini juga berfungsi agar laju produksi tidak terganggu oleh gangguan yang terjadi dalam sistem produksi, oleh karena itu buffer ini dikenal juga sebagai buffer pelindung (protective buffer). Buffer terdiri dari 2 yaitu time buffer dan stock buffer. Rope melambangkan titik kendali yang menentukan kapan bahan baku dilepaskan ke lantai pabrik. 


\section{Bottleneck dan Capacity Constraint Resource (CCR)}

Bottleneck didefinisikan sebagai suatu sumber yang memiliki kapasitas yang sama atau lebih kecil dari yang dibutuhkan. Sumber bottleneck merupakan kendala dalam sistem yang mempunyai output terbatas. CCR adalah kapasitas yang dekat dengan standar. Tabel identifikasi bottleneck dan CCR dapat dilihat pada Tabel 1 [1].

Tabel 1. Identifikasi CCR

\begin{tabular}{|c|c|c|}
\hline & Bottleneck & Non-Bottleneck \\
\hline CCR & $\begin{array}{l}\text { Menghambat aliran aktual, baik dalam jumlah } \\
\text { dan waktu. } \\
\text { Harus dipertimbangkan dalam perencanaan } \\
\text { aliran produk. }\end{array}$ & $\begin{array}{l}\text { Menghambat aliran waktu yang sebenarnya, } \\
\text { tetapi bukan kuantitas. } \\
\text { Harus dipertimbangkan dalam perencanaan } \\
\text { aliran produk. }\end{array}$ \\
\hline $\begin{array}{l}\text { Non- } \\
\text { CCR }\end{array}$ & $\begin{array}{l}\text { Boleh menghambat aliran aktual, } \\
\text { baik dalam jumlah dan waktu. } \\
\text { Tidak membutuhkan pertimbangan dalam } \\
\text { perencanaan aliran produk. }\end{array}$ & $\begin{array}{l}\text { Bukan kendala aliran, baik dalam kuantitas atau } \\
\text { dalam waktu. } \\
\text { Tidak membutuhkan pertimbangan dalam } \\
\text { perencanaan aliran produk. }\end{array}$ \\
\hline
\end{tabular}

\section{Pengujian Data}

Uji kenormalan data bertujuan untuk menentukan apakah data-data yang diperoleh telah berdistribusi normal atau tidak [3]. Uji ini digunakan untuk mengetahui apakah suatu populasi mengikuti suatu distribusi teoritis tertentu. Pengujian normalitas dengan uji Kolmogorov Smirnov menggunakan software IBM SPSS Statistic 20. Syarat yang digunakan dalam uji Kolmogorov Smirnov yaitu sebagai berikut [4]: iika nilai Kolmogorov Smirnov Z > 0,05, maka data berdistribusi normal dan jika nilai Kolmogorov Smirnov Z < 0,05 , maka data tidak berdistribusi normal

Uji keseragaman data bertujuan untuk mengetahui apakah hasil pengukuran waktu cukup seragam. Suatu data dikatakan seragam apabila data tersebut berada dalam rentang batas kontol. Batas kontrol yang digunakan yaitu batas kontrol atas (BKA) dan batas kontrol bawah (BKB). Uji keseragaman data yang digunakan dalam penelitian ini adalah metode sub group. Menurut Walpole, rumus yang digunakan dalam uji keseragaman data antara lain [5]:

\section{Rata-rata sub group :}

$\bar{x}=\frac{\sum X i}{\mathrm{~K}}$

Dimana $: \bar{x}=$ harga rata-rata dari subgroup

$\mathrm{Xi}=$ data yang terdapat pada subgroup

$\mathrm{K}=$ jumlah subgroup yang terbentuk

\section{Standar deviasi :}

$\sigma=\sqrt{\frac{\sum(X i-\bar{x})^{2}}{\mathrm{~N}-1}}$

Dimana : $\mathrm{N}=$ jumlah pengamatan yang dilakukan 


$$
\mathrm{X} \mathrm{i}=\text { waktu yang diamati selama pengukuran yang telah dilakukan }
$$

$$
\begin{aligned}
& \text { Standar deviasi dari distribusi harga rata-rata subgroup : } \\
& \sigma x=\frac{\sigma}{\sqrt{n}}
\end{aligned}
$$

Dimana : n adalah besarnya subgroup

1. Batas kontrol atas dan bawah:

$\mathrm{BKA}=\bar{x}+k . \sigma x$

$\mathrm{BKB}=\bar{x}-k . \sigma x$

Uji kecukupan data dilakukan untuk mengetahui apakah data yang diambil sudah cukup atau belum untuk mewakili kondisi sebenarnya. Uji kecukupan data digunakan dengan rumus antara lain :

Tentukan tingkat ketelitian dan tingkat keyakinan yang dikehendaki.

Hitung N'

$\mathrm{N}^{\prime}=\left[\frac{\mathrm{k} / \mathrm{s} \sqrt{\mathrm{N} \sum \mathrm{x}_{\mathrm{i}}{ }^{2}-\left(\sum \mathrm{x}_{\mathrm{i}}\right)^{2}}}{\sum \mathrm{x}_{\mathrm{i}}}\right]^{2}$

Dimana:

$\mathrm{s}=$ persentase tingkat ketelitian

$\mathrm{N}=$ jumlah pengukuran yang telah dilakukan

$\mathrm{N}^{\prime}=$ jumlah pengukuran minimum yang diperlukan

Jika N' < N, maka pengamatan yang dilakukan dianggap cukup. Sebaliknya jika N' $>\mathrm{N}$, maka perlu dilakukan pengamatan lagi.

\section{Perhitungan Waktu Baku}

Perhitungan Waktu Baku diperoleh dari hasil pengukuran waktu dengan menggunakan stopwatch. Waktu baku didapatkan dari waktu proses pada setiap stasiun kerja. Terdapat beberapa pengukuran waktu yang terlibat dalam perhitungan waktu baku antara lain yaitu: waktu siklus, waktu normal dan waktu baku

\section{Perbaikan Sistem Kerja}

Peta kerja merupakan salah satu alat sistematis dan jelas untuk berkomunikasi secara luas melalui peta kerja ini dapat memperoleh informasi yang diperlukan untuk memperbaiki suatu metode kerja. Perbaikan sistem kerja merupakan hasil dari usulan perbaikan dimana perbaikan sistem kerja berupa peta kerja yaitu peta tangan kiri tangan kanan [3].

\section{Perhitungan Biaya Depresiasi}

Menurut I Nyoman Pujawan, depresiasi adalah penurunan nilai suatu properti atau aset karena waktu pemakaian. Besarnya depresiasi tahunan yang dikenal pada suatu property akan tergantung pada beberapa hal yaitu: ongkos investasi dari property, tanggal 
pemakaian awalnya, estimasi masa pakai, nilai sisa yang ditetapkan, dan metode depresiasi yang ditetapkan.

Metode yang digunakan untuk perhitungan biaya depresiasi yaitu metode depresiasi garis lurus. Metode garis lurus didasarkan atas asumsi bahwa berkurangnya nilai suatu aset secara linier terhadap waktu dan umur dari aset tertentu.

\section{Routing Sheet}

Pengurutan produksi (routing sheet) adalah tabulasi langkah-langkah yang dicakup dalam memproduksi komponen tertentu dan rincian yang perlu dari hal-hal yang berkaitan [7]. Routing sheet berguna untuk menghitung jumlah mesin yang dibutuhkan dan menghitung jumlah part yang harus dipersiapkan untuk memperoleh sejumlah produk yang diinginkan.

\section{METODOLOGI PENELITIAN}

Flowchart metodologi penelitian dapat dilihat pada Gambar 1.



Gambar 1. Flowchart Metodologi Penelitian

HASIL DAN PEMBAHASAN

\section{Aliran Proses Produksi Rib}

Aliran proses produksi Rib dapat dilihat pada Gambar 2. 


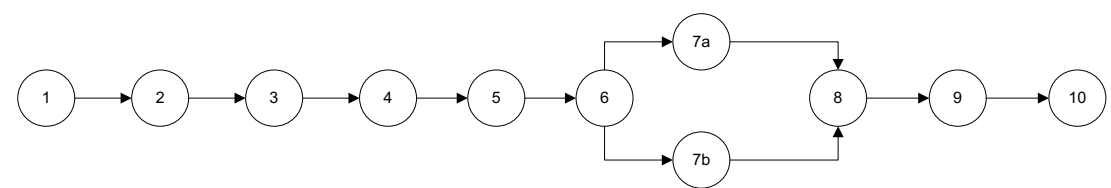

Gambar 2. Aliran Proses Produksi

Keterangan gambar:

1. Loading benang

2. Mengantar benang ke mesin

3. Rajut

4. Timbang berat kain

5. Pemeriksaan cacat kain

6. Jahit

7a. Celup

7b. Cuci

8. Peras

9. Drayer

10. Compactor

Waktu baku proses Rib dapat dilihat pada Tabel 2.

\begin{tabular}{ccc}
\multicolumn{3}{c}{ Tabel 2. Waktu Baku Proses Produksi Rib } \\
\hline No & Aktivitas & Waktu Baku (Menit) \\
\hline 1 & Loading & 6,43 \\
2 & Antar & 2,34 \\
3 & Rajut & 221,14 \\
4 & Timbang & 0,01 \\
5 & QC & 4,17 \\
6 & Jahit & 47,08 \\
7 & Celup & 820,38 \\
8 & Cuci & 164,08 \\
9 & Peras & 40,34 \\
10 & Drayer & 20,35 \\
11 & Compactor & 14,63 \\
\hline \multicolumn{3}{c}{ Total } \\
\hline
\end{tabular}

\section{Perhitungan Kapasitas}

Hasil perhitungan kapasitas masing-masing stasiun kerja pada Departemen Knitting dan BDF dapat dilihat pada Tabel 3 dan Tabel 4. 
Tabel 3. Hasil Perhitungan Kapasitas Departemen Knitting

\begin{tabular}{|c|c|c|c|c|}
\hline Jenis & Inch & $\begin{array}{l}\text { Jumlah } \\
\text { Mesin }\end{array}$ & $\begin{array}{c}\text { Kapasitas Yang } \\
\text { Diperlukan (Menit) }\end{array}$ & $\begin{array}{l}\text { Kapasitas Yang } \\
\text { Tersedia (Menit) }\end{array}$ \\
\hline \multirow{14}{*}{ Rib } & $11 / 16$ & 1 & 37151 & 19316 \\
\hline & $12 / 16$ & 2 & 43452 & 38632 \\
\hline & $13 / 16$ & 2 & 43452 & 40219 \\
\hline & $14 / 16$ & 5 & 43669 & 100548 \\
\hline & $15 / 16$ & 11 & 36282 & 221206 \\
\hline & $16 / 16$ & 15 & 43669 & 301644 \\
\hline & $17 / 16$ & 14 & 33675 & 281534 \\
\hline & $16 / 18$ & 2 & 31068 & 40219 \\
\hline & $17 / 18$ & 6 & 30851 & 120658 \\
\hline & $18 / 18$ & 6 & 39758 & 120658 \\
\hline & $19 / 18$ & 3 & 37368 & 60329 \\
\hline & $20 / 18$ & 4 & 30416 & 80438 \\
\hline & $30 / 18$ & 3 & 11515 & 60329 \\
\hline & $36 / 18$ & 1 & 18250 & 19316 \\
\hline \multirow{2}{*}{ Sk } & $34 / 28$ & 5 & 10863 & 96579 \\
\hline & $36 / 28$ & 1 & 22812 & 19316 \\
\hline \multirow{6}{*}{$\begin{array}{c}\text { Rib } \\
\text { spandek }\end{array}$} & $16 / 18$ & 1 & 194174 & 965790 \\
\hline & $12 / 18$ & 1 & 244415 & 965790 \\
\hline & $13 / 18$ & 1 & 244415 & 965790 \\
\hline & $14 / 18$ & 2 & 264783 & 1931580 \\
\hline & $15 / 18$ & 2 & 264783 & 1931580 \\
\hline & $13 / 16$ & 1 & 271572 & 965790 \\
\hline \multirow{3}{*}{$\begin{array}{c}\text { Sk } \\
\text { spandek }\end{array}$} & $30 / 14$ & 3 & 325886 & 13907376 \\
\hline & $30 / 24$ & 2 & 684361 & 9271584 \\
\hline & $30 / 28$ & 2 & 619184 & 8890560 \\
\hline
\end{tabular}

Tabel 4. Hasil Perhitungan Kapasitas Departemen BDF

\begin{tabular}{ccc}
\hline Mesin & $\begin{array}{c}\text { Kapasitas Yang } \\
\text { Diperlukan (Menit) }\end{array}$ & $\begin{array}{c}\text { Kapasitas Yang } \\
\text { Tersedia (Menit) }\end{array}$ \\
\hline Jahit & 233058 & 71442 \\
Celup & 172280 & 119070 \\
Cuci & 77525 & 62710 \\
Peras & 124530 & 95256 \\
Drayer & 204605 & 47628 \\
Compactor & 89238 & 71442 \\
\hline
\end{tabular}

\section{Pengelompokan Stasiun Kerja}

Stasiun Kerja dikelompokan berdasarkan tabel, Stasiun kerja dapat dilihat pada Tabel 6 dan Tabel 7.

Tabel 6. Pengelompokan Stasiun Kerja Departemen Knitting

\begin{tabular}{ccc} 
& Bottleneck & Non Bottleneck \\
\hline capacity-constraint & $12 / 16,13 / 16$, & $14 / 16,16 / 18,19 / 18,20 / 18,30 / 18,36 / 18,34 / 28$ \\
resource & $36 / 28$ & $15 / 16,17 / 16,12 / 18,13 / 18,14 / 18,15 / 18,16 / 18,13 / 16,30 / 14,30$ \\
NON capacity- & $11 / 16$ & $/ 24,30 / 28$ \\
constraint resource & & 1
\end{tabular}


Tabel 7. Pengelompokan Stasiun Kerja Departemen BDF Bottleneck

Capacity-constraint Resource

Celup, Cuci, Peras, Compactor

NON Capacity-constraint Resource Jahit dan Dryer

\section{Drum Buffer Rope}

Drum buffer rope pada stasiun kerja Departemen Knitting dan Departemen BDF dapat dilihat pada Gambar 3 dan Gambar 4.

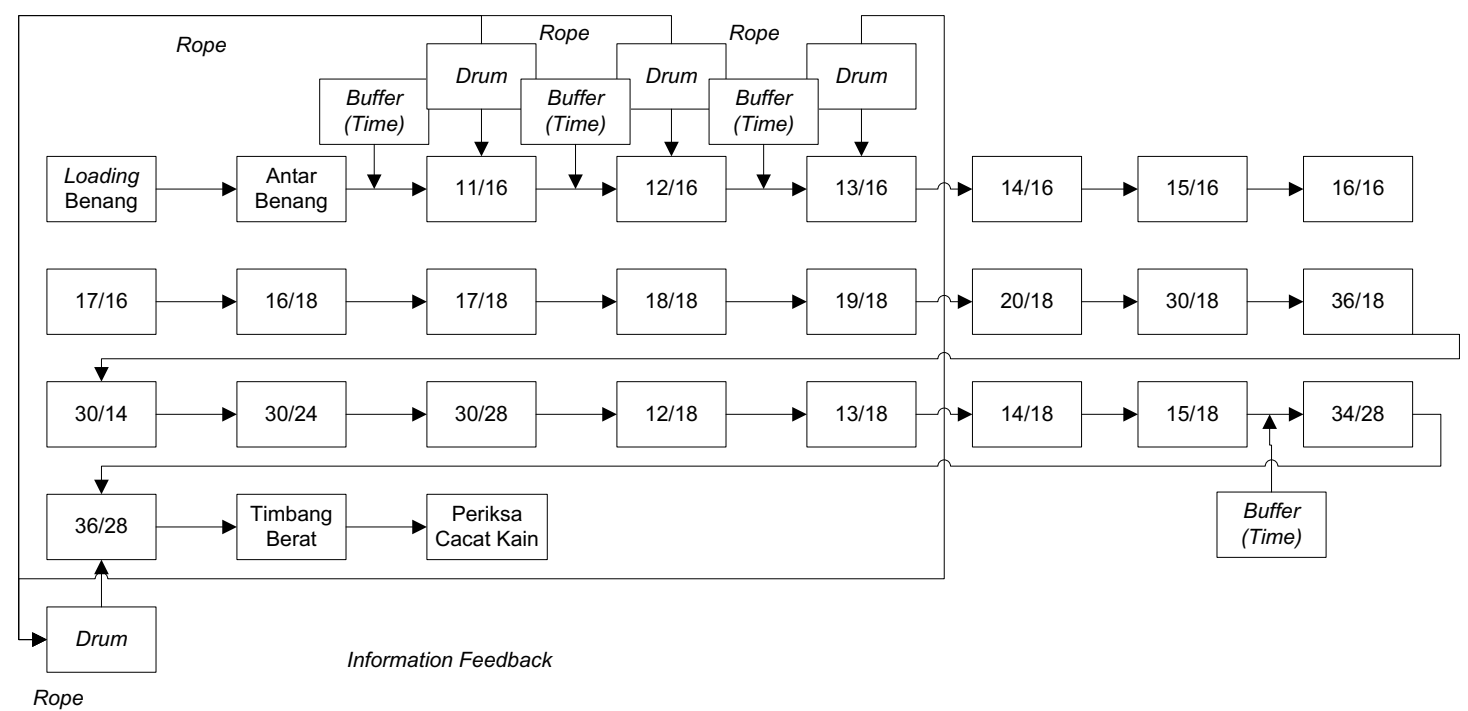

Gambar 3. DBR Departemen Knitting

Berdasarkan Gambar 3. Time Buffer diletakkan sebelum stasiun bottleneck/. Bottleneck Resource/Drum terletak pada stasiun yang memiliki kekurangan kapasitas waktu yaitu 11/16, 12/16, 13/16 dan 36/28. Rope sebagai tali yang menginformasikan bahwa semua kegiatan terletak di dalamnya.

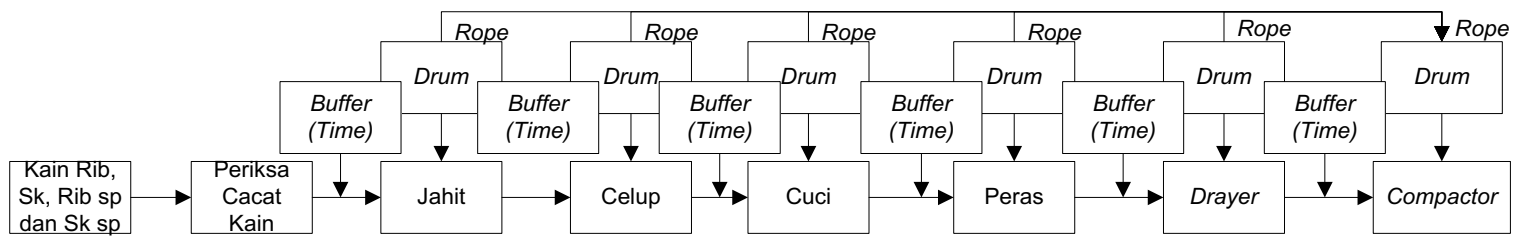

Gambar 4. DBR Departemen BDF

Berdasarkan Gambar 4. Time Buffer diletakkan sebelum stasiun kerja bottleneck. Drum/Bottleneck Resource adalah pada stasiun kerja yang memiliki kapasitas waktu yaitu semua stasiun kerja dalam Departemen BDF. Rope terletak sebagai tali yang menginformasikan semua kegiatan di dalamnya. 


\section{Usulan Perbaikan untuk Peningkatan Kapasitas}

Analisa DBR pada Departemen Knitting dan BDF dan kekurangan kapasitas. Hasil perhitungan kekurangan kapasitas dapat dilihat pada Tabel 8.

Tabel 8. Hasil Perhitungan Kekurangan Kapasitas

\begin{tabular}{cccccc}
\hline Jenis & Inch & $\begin{array}{c}\text { Jumlah } \\
\text { Mesin }\end{array}$ & $\begin{array}{c}\text { Kapasitas Yang } \\
\text { Diperlukan (Menit) }\end{array}$ & $\begin{array}{c}\text { Kapasitas Yang } \\
\text { Tersedia (Menit) }\end{array}$ & $\begin{array}{c}\text { Kekurangan } \\
\text { Kapasitas (Menit) }\end{array}$ \\
\hline \multirow{2}{*}{ Rib } & $11 / 16$ & 1 & 37151 & 19316 & -17835 \\
& $12 / 16$ & 2 & 43452 & 38632 & -4820 \\
\hline Sk & $13 / 16$ & 2 & 43452 & 40219 & -3232 \\
\hline
\end{tabular}

Usulan perbaikan yang dilakukan adalah perbaikan sistem kerja, penambahan mesin dan lembur hari kerja \& hari libur. Perbaikan sistem kerja dilakukan dengan menggunakan peta kerja yaitu peta tangan kiri dan tangan kanan sebelum dan sesudah perbaikan. Penambahan mesin dilakukan berdasarkan kekurangan kapasitas produksi dengan menggunakan biaya depresiasi mesin per bulan.

Setelah didapatkan data dari routing sheet kemudian dibuat tabel penambahan mesin. Penambahan mesin dapat dilihat pada Tabel 9.

Tabel 9. Penambahan Mesin

\begin{tabular}{ccccc}
\hline Proses Operasi & Nama Mesin & $\begin{array}{c}\text { Jumlah Mesin } \\
\text { Yang Dibutuhkan } \\
\text { (unit) }\end{array}$ & $\begin{array}{c}\text { Jumlah Mesin } \\
\text { Yang Tersedia } \\
\text { (unit) }\end{array}$ & $\begin{array}{c}\text { Kekurangan } \\
\text { Mesin (unit) }\end{array}$ \\
\hline \multirow{3}{*}{ Rajut } & $11 / 16$ & 3 & 1 & 2 \\
& $12 / 16$ & 3 & 1 & 2 \\
& $13 / 16$ & 3 & 1 & 2 \\
\hline Jahit & $36 / 28$ & 2 & 1 & 3 \\
\hline Dryer & Jahit & 6 & 3 & 2 \\
\hline Celup & Dryer & 4 & 2 & 3 \\
\hline
\end{tabular}

Biaya depresiasi per bulan pada setiap mesin didapatkan data dari penambahan mesin. Biaya total depresiasi mesin dapat dilihat pada Tabel 10.

Tabel 10. Biaya Total Depresiasi Mesin ( 1 bulan)

\begin{tabular}{llr}
\hline \multicolumn{1}{c}{ Jenis Biaya/bulan } & \multicolumn{1}{c}{ Jumlah } \\
\hline Biaya Depresiasi Mesin Rib & $\mathrm{Rp}$ & 99.311 \\
Biaya Depresiasi Mesin Sk & $\mathrm{Rp}$ & 139.036 \\
Biaya Depresiasi Mesin Jahit & $\mathrm{Rp}$ & 50.469 \\
Biaya Depresiasi Mesin Dryer & $\mathrm{Rp}$ & 556.143 \\
Biaya Depresiasi Mesin Celup & $\mathrm{Rp} 14.241 .286$ \\
\hline \multicolumn{1}{c}{ Total Biaya } & $\mathrm{Rp} \mathrm{15.086.245}$ \\
\hline
\end{tabular}

Lembur hari kerja \& hari libur diperlukan karena adanya kekurangan kapasitas pada Departemen BDF dengan stasiun kerja jahit, cuci, peras, dryer, dan compactor. Totsl biaya lembur dapat dilihat pada Tabel 11. 
Tabel 11. Total Biaya Lembur ( 1 bulan )

\begin{tabular}{llr}
\hline \multicolumn{1}{c}{ Jenis Biaya/bulan } & \multicolumn{1}{c}{ Jumlah } \\
\hline Biaya Listrik Lembur Hari Kerja & $\mathrm{Rp}$ & 2.129 .400 \\
Biaya Listrik Lembur Hari Libur & $\mathrm{Rp}$ & 4.968 .600 \\
Upah Lembur Operator & $\mathrm{Rp}$ & 11.580 .347 \\
\hline Total Biaya & $\mathrm{Rp}$ & 18.678 .347 \\
\hline
\end{tabular}

Biaya yang dikeluarkan perusahaan dengan usulan perbaikan yang dilakukan sebesar Rp. 36.962.592. Usulan perbaikan yang dilakukan adalah biaya total depresiasi mesin 1 bulan + lembur hari kerja \& hari libur 1 bulan + penambahan karyawan.

\section{Perhitungan Biaya}

Perkiraan biaya yang dikeluarkan oleh perusahaan untuk memenuhi kekurangan kapasitas dengan penambahan karyawan pada Departemen Knitting sebanyak 4 orang dan Departemen BDF sebanyak 9 orang. Perhitungan biaya 1 bulan dari depresiasi mesin 1 bulan + lembur hari kerja \& hari libur 1 bulan + penambahan karyawan sebesar Rp36.962.592.

\section{Analisa Biaya Peningkatan}

Perhitungan analisa biaya peningkatan untuk memenuhi kekurangan kapasitas produksi sebesar Rp. 1.155.081, dimana peningkatan kapasitas produksi yang sebelumnya 168 unit dalam 1 bulan menjadi 200 unit dalam 1 bulan. Analisa biaya peningkatan didapatkan dengan rumus sebagai berikut:

$\frac{\text { Total perhitungan biaya }}{\text { Peningkatan kapasitas }}=\frac{\text { Rp.36.962.592 }}{32 \text { unit }}=$ Rp 1.155 .081

\section{KESIMPULAN}

Dari penelitian yang dilakukan dapat ditarik kesimpulan sebagai berikut: Stasiun yang menjadi penghambat yaitu rajut Departemen Knitting pada Rib 11/16, 12/16, 13/16 dan 36/28 sedangkan penghambat pada Departemen BDF terletak pada stasiun kerja jahit dan dryer. Bottleneck pada Departemen Knitting dan BDF terdapat CCR dan Non CCR. Bottleneck CCR pada Departemen Knitting adalah Rib 12/16, 13/16 dan Sk 36/28 sedangkan Non CCR adalah Rib 11/16, bottleneck Non CCR pada Departemen BDF adalah jahit dan dryer sedangkan CCR adalah celup, cuci, peras, compactor. Penanganan lini pembuatan kain dan pembuatam warna dilakukan dengan menghitung kapasitas yang diperlukan dan kapasitas yang tersedia dengan dilakukan pendekatan theory of constraint untuk menghindari terjadinya bottleneck pada stasiun kerja serta memberikan usulan perbaikan yang tepat untuk perusahaan. Usulan perbaikan yang dilakukan adalah perbaikan sistem kerja, penambahan mesin dan lembur hari kerja \& hari libur. 


\section{DAFTAR PUSTAKA}

[1] Goldratt, E.M. 1990. What is this thing called Theory Of Constraints and how should it be implemented? North River Press Great Barrington, Massachusetts: Publishing Corporation.

[2] Umble, M., Srikanth M.L. 1996. Synchronous Manufacturing. Guilford, Conneticut. Penerbit : The Spectrum Publishing Company.

[3] Sutalaksana, I.Z. Ruhana, A., Jann H.T. 2006. Teknik Perancangan Sistem Kerja. Bandung: Institut Teknik Bandung.

[4] Kolmogorov, A.N. (1992). On the empirical determintation of a distribution law. In A. N. Shiryayev (Ed.), Selected works of A.N. Kolmogorov: Probability Theory and Mathematical Statistics (Vol.2, pp. 139-146). Dordrecht, Netherland: Kluwer Academic Publisher.

[5] Walpole, Ronald E. 1993. Pengantar Statistika. Jakarta : PT Gramedia Pustaka Utama

[6] Pujawan. I Nyoman. 2005. Supply Chain Management. Suarabaya: Penerbit Guna Widya.

[7] Apple, James M. 1990. Tata Letak Pabrik dan Pemindahan Bahan. Edisi Ketiga. Bandung: Insitut Teknik Bandung. 